De Jure: Jurnal Hukum dan Syari'ah

Vol. 11, No. 1, 2019, h. 63-75

ISSN (Print): 2085-1618, ISSN (Online): 2528-1658

DOI: http://dx.doi.org/10.18860/j-fsh.v11i1.6611

Available online at http://ejournal.uin-malang.ac.id/index.php/syariah

\title{
Submission of Marital Dispensation for Religious Courts in Central Java: Study of Minimum Pair Age Standards Along With Judge's Attitudes and Wisdomes
}

\author{
Kholifatun Nur Mustofa \\ Universitas Islam Negeri Sunan Kalijaga Yogyakarta, Indonesia \\ ofakholifatunnm@gmail.com
}

\begin{abstract}
This paper examines the minimum age limit for filing a marital dispensation focused on the Central Java Religious Courts. This paper examines the judge's policy in the marital dispensation in religious courts in Central Java regarding the marital age limit by using anthropology approach. by reviewing the judges' decisions in the marital dispensation cases focusing on the tendency of the brides' ages to see the minimum age to have marital dispensation in each region. The research shows that the lowest age to file a marital dispensation in Central Java is 12 years 9 months for female, and 15 years 10 months for male. The majority of judges do not consider the age of the parties, but rather the reasons and conditions of the party submitting.

Artikel ini membahas batas usia minimum untuk mengajukan dispensasi perkawinan yang berfokus pada Pengadilan Agama Jawa Tengah. Makalah ini membahas kebijakan hakim dalam dispensasi perkawinan di pengadilan agama di Jawa Tengah mengenai batas usia perkawinan dengan menggunakan pendekatan antropologi. dengan meninjau keputusan hakim dalam kasus dispensasi perkawinan yang berfokus pada kecenderungan usia pengantin untuk melihat usia minimum untuk memiliki dispensasi perkawinan di setiap wilayah. Penelitian menunjukkan bahwa usia terendah untuk mengajukan dispensasi perkawinan di Jawa Tengah adalah 12 tahun 9 bulan untuk perempuan, dan 15 tahun 10 bulan untuk laki-laki. Mayoritas hakim tidak mempertimbangkan usia partai, melainkan alasan dan kondisi dari partai yang mengajukan.
\end{abstract}

Keywords: underage marriage; marital dispensation; religius court.

\section{Introduction}

Marriage is an inner and outer bond between a man and a woman as a husband and wife with the purpose to form a happy and eternal family or household based on the one God. While the notion of marriage in the Compilation of Islamic Law (KHI) is a substantial contract 'mitssaqan ghalidza' to obey Allah's commands as an observance. One condition for someone to do marriage is the fulfillment of the age of marriage. The marital law regulates that marriageable age for a man is at least 19 years old and for a woman is 16 years. These rules also reap the pros and cons of whether or not the 
minimum age for marriage is relevant. One of them is because the provisions in the Child Protection Law considers that a person under 18 as a child. Therefore, several institutions thought that 16 years for women no longer be the minimum marriage limit and raised to 18 years, but the Constitutional Court rejected the effort.

One of the reasons from the institutions to raise the age of 18 years is based on the maturity of a woman in terms of fertility. The period in terms of reproduction is the minimum maturity of a woman to get married. ${ }^{1}$ Many health observers even explained that marriages carried out under the age of 21 (women) have an impact on the risk of cervical cancer, due to the unpreparedness of the reproductive organs for sexual intercourse. $^{2}$ In addition to reproductive readiness, marriage also requires physical, psychological, social, economic and intellectual preparation, because if the readiness is not perfect, it will result in the vulnerability of violence and discrimination. ${ }^{3}$ The minimum marriage limit should be 20 years for men and women without distinguishing the two. ${ }^{4}$

Maria Farida Indrati ${ }^{5}$ reveals that someone who gets married under 18 is categorized as underage marriage because he or she is not physically, physiologically, and psychologically ready to take responsibility for marriage. ${ }^{6}$ Therefore, the minimum age limit for marriage as stipulated in the marital law is time to change, which has an impact on efforts to change the culture and traditions of child marriage. ${ }^{7}$ Some institutions seek to increase the minimum age of marriage even though the judge's consideration decided to reject the application for judicial review No. 30-74 / PUU-XXI / 2014. The effort to submit judicial review was again submitted in 2017 by three applicants who were victims of underage marriage to equate the minimum age limit for women and men by 19 years old. The submission of judicial review No. 22 / PUU-XV / 2017 was then accepted as the Constitutional Court Judges stated that the difference of age limit between men and women is a discrimination ${ }^{8}$. However, the judge did not mention the age limit that should be used because the Constitutional Court would give a space for the legislators to follow the development of law and society. Then the court gave the House of representative a 3year grace period to harmonize between the Marriage Law and the Child Protection Act. ${ }^{9}$

According to the author the efforts above should be appreciated as it is to reduce the level of underage marriage. However, another problem occurs because there is still legal leniency for someone to do an underage marriage by applying to a religious court

\footnotetext{
${ }^{1}$ Marmi, Kesehatan Reproduksi (Yogyakarta: Pustaka Pelajar, 2014), 18.

${ }^{2}$ Marhumah, Hak-Hak Dalam Keluarga (Yogyakarta: Pusat Studi Wanita UIN Sunan Kalijaga, 2009), 95.

${ }^{3}$ Mahkamah Konstitursi Republik Indonesia "Usia Minimal 16 Tahun Bagi Perempuan untuk Menikah Tidak Langgar Konstitusi” http://www.mahkamahkonstitusi.go.id/index.php?page=web.Berita\&id=11150\#.Wk4HFDR6O00 on date 20 December 2018.

${ }^{4}$ Lufaefi, "Upgrading Hukum Perkawinan Di Indonesia: Upaya Pencegahan Kekerasan Terhadap Kaum Perempuan,” Jurnal Musãwa, Vol. 16, No. 1, Januari 2017, 103.

${ }^{5}$ Maria Farida Indrati also confirms the age limit of 18 years is one of the judges of the Constitutional

Court who ruled the Judicial Review Case which was submitted in 2014.

${ }^{6}$ Putusan Mahkamah Konstitusi No 30-74/PUU-XXI/2014 contains about filing the addition of the minimum age limit for marriage. She is quoted on date 20 December 2018, 238.

${ }^{7}$ Putusan Mahkamah Konstitusi No 30-74/PUU-XXI/2014, 239.

${ }^{8}$ Putusan Mahkamah Konstitusi No 22/PUU-XV/2017, 59.

${ }^{9}$ Presentation of Mr. Dr. Wahidudin Adams (he is one of the Constitutional Court Judges who ruled Case No: 22 / PUU-XV / 2017 concerning Marriage Age) at a national seminar with the theme "Usia Perkawinan Pasca Putusan MK No 22 PUU-XV-2017'. He performed at Jambuluwuk Hotel Yogyakarta on February 8, 2019.
} 
through the marital dispensation ${ }^{10}$ as it is regulated in Law No. 1 of 1974 article 7 paragraph 2. ${ }^{11}$ This makes the writer interested in researching because the provisions of the marital dispensation do not regulate the minimum age limit to apply for the marital dispensation. As a result, child marriages will still occur even though the minimum age limit for marriage is increased following the policy-making law. This religious court judges have a vital role in granting and rejecting the petitioners' request for the dispensation.

Many previous researchers have conducted studies related to underage marriage. Sofia, for instance, examines how the marital law views the concept of maturity for a marriage, and what problems arise by considering medical point of views and the Child Protection Act. The findings of the above research stated that marriage should only be possible if both parties have matured physically, mentally and materially. The Marriage Law is not consistent in regulating the minimum age limit as the dispensation rules have no limits. Thus, one can apply for the dispensation even though they are still far below the minimum age. In addition, there is no sanction in the law if someone violates the provisions of the Act. The state should take a share due to its full authority through the law. ${ }^{12}$ The research above has the same theme, namely about marriage dispensation, but the previous research focused on the substance, while this study focused on the cases in Central Java religious courts.

Another study examined the marriage of girls carried out under 18 years old by looking at the factors and the impact on the perpetrators. The findings of this study stated that as many as $25 \%$ of women in Indonesia marry under the age of 18 . Poverty is often used as an excuse for the underage marriage. In fact, the condition is getting worse because the married women have low education. ${ }^{13}$ The research above has similarities in revealing underage marriages, but the paper focuses more on marriage conducted under the age of 16 (female) and 19 years (male). The difference between this paper and above research is in the focus of the case. This paper research is more on the verdicts of religious courts, while previous research is more about the community. Then the Ministry of Religion's research focuses on research in Banten, Indramayu, Brebes, and Malang. It is reviewing the impact that is obtained for underage marriages seen in terms of economic, social and reproductive health. The results of the study concluded that the sexual intercourse carried out by children harms to health such as miscarriage and death. ${ }^{14}$

Thus, the author is interested in studying more deeply about the marriage dispensation that focuses on Central Java, using the anthropological approach. This paper examines the judge's standard of minimum age limit in establishing cases of marriage dispensation in Central Java and the judges' considerations in granting a marital dispensation for the underage marriage. The data are collected through library observation and taken from the Supreme Court focusing on cases of marital dispensation in Central

\footnotetext{
${ }^{10}$ Marriage dispensation is a term used for requests submitted by parents of prospective groom or bride or both to request permission so that the applicant's child is permitted to marry underage specified in the applicable Marriage Law.

11 The deviation in paragraph (1) of this article can be requested for dispensation to the Court or other officials required by both male and female parents.

12 Sofia Hardani, “Analisis Tentang Batas Umur untuk Melangsungkan Perkawinan Menurut PerUndangUndangan di Indonesia,” An-Nida' : Jurnal Pemikiran Islam, Vol. 40, No 2 Juli- Agustus 2015, 127.

${ }^{13}$ Subdirectory Statistik Rumah Tangga, Kemajuan yang Tertunda: Analisis Data Perkawinan Usia Anak Indonesia, (Jakarta: Badan Pusat Statistik 2015), 130-138.

${ }^{14}$ Kustini, Menelusuri Makna di Balik Fenomena Perkawinan di Bawah Umur dan Perkawinan Yang Tidak Dicatatkan (Jakarta: Badan Litbang dan Diklat, Kementrian Agama RI 2013), 6.
} 
Java by tracing the youngest age from each district. The stipulations outlined in this paper constitute the determination of cases of marriage dispensation which are delivered by the judge reinforced by journals and other related writings.

\section{Minimum Case Data for Perpetrators of Submission of Marriage Dispensation in Central Java and Reasons for Submission}

This study, in this case, reveals cases of marriage dispensation in each district which is the scope of Central Java. And then, it looks for the youngest example of marriage dispensation in each region. Marriage compensation data in each area in Central Java can be seen in the following columns:

Table 1

\begin{tabular}{|c|c|c|c|}
\hline No & Case Number & Age of Men & Age of Women \\
\hline$(1)$ & Number 0073/Pdt.P/2013/PA Pwd. ${ }^{15}$ & 25 Years & 13 Years 4 Months \\
\hline (2) & Number 0162/Pdt.P/2016/PA.Kd1 ${ }^{16}$ & 20 Years & 13 Years \\
\hline (3) & Number 0102/Pdt.P/2014/PA.Jpr. ${ }^{17}$ & 21 Years & 13 Years 9 Months \\
\hline (4) & Number 066/Pdt.P/2015/PA.Ba. ${ }^{18}$ & 17 Years & 13 Years 3 Months \\
\hline$(5)$ & Number 146/Pdt.P/2013/PA.Bms. ${ }^{19}$ & - & 13 Years 1 Month \\
\hline (6) & Number 0003/Pdt.P/2015/PA.Pkl. ${ }^{20}$ & 17 Years 9 Months & 13 Years 3 Months \\
\hline (7) & Number 0030/Pdt.P/2015/PA.Bla. ${ }^{21}$ & - & 13 Years 5 Months \\
\hline$(8)$ & Number 0138/Pdt.P/2014/PA.Klt. ${ }^{22}$ & 25 Years 7 Months & 13 Years 9 Months \\
\hline$(9)$ & Number 0011/Pdt.P/2012/PA/Mgl. ${ }^{23}$ & 20 Years & 13 Years 11 Months \\
\hline
\end{tabular}

15 The reason presented in the trial was to avoid things that were forbidden by religion, the bride candidate was 13 years 4 months old, while the prospective husband was 25 years old, the work of a paddy slipper with 1.500 .000 income every month.

16 The reason given in the trial was Fear of doing things that were forbidden by religion, the prospective bride was 13 years old, while her husband was 20 years working as a construction worker, the income earned was Rp 60.000 every day.

${ }^{17}$ The reason presented in the trial was because he had been dating for 9 months, and got engaged 5 months ago. Prospective bride 13 years 11 months while potential husband is 21 years old, a job as a driver with an income of Rp 3.000.000 every month.

18 The reasons presented in the trial were having a relationship (dating) for 1 year and 3 months. Prospective husband aged 17 years 9 months Employment of merchants, income not mentioned in the copy of the decision, a prospective bride is 13 years 3 months.

${ }^{19}$ The reasons presented in the trial were the two of them knew for 1 year, the bride's parents agreed to marry them so they would not do things that they did not want, while the age of the prospective husband was not mentioned. Employment, earning Rp 800.000 every month, prospective bride 13 years 1 month.

${ }^{20}$ The reason given in the trial was dating 2 years and having been pregnant for 2 months, the prospective bride was 13 years 8 months, while the age of the potential husband was 19 years 5 months. Workers of batik artisans. Income of Rp 35.000 every day.

${ }^{21}$ The reason given in the trial was that it was engaged 2 years and had been applied for 2 months ago. Prospective bride, 13 years 5 months, an age of potential husband, not stated. Farmer's job. Income of Rp 1.000 .000 every month.

${ }^{22}$ The reasons presented in the trial were that they were familiar with the prospective husband for 1 year. Submission because if you do not get married soon fear something will happen that violates the shari'a. The age of prospective brides is 13 years 9 months, while the age of potential husbands is 25 years 7 months. Workers work, earning Rp 1.000.000 every month.

${ }^{23}$ The reasons presented in the trial were 1-year dating, and already pregnant, but in the copy of the decision, it was not stated how many months the child was pregnant. The age of a prospective bride is 13 years 11 months, while the generation of a potential husband is 20 years. Construction work. Earnings of Rp 750.000 every month. 


\begin{tabular}{|c|c|c|c|}
\hline$(10)$ & Number 0061/Pdt.P/2015/PA.Pt. ${ }^{24}$ & 21 Years & 13 Years 11 Months \\
\hline$(11)$ & Number 200/ Pdt.P//2014/PA.Pt. ${ }^{25}$ & 31 Years 6 Months & 13 Years 1 Months \\
\hline$(12)$ & Number 987/ Pdt.P/2012/PA.Mlg. ${ }^{26}$ & 21 Years & 13 Years \\
\hline (13) & Number 0244/Pdt.P/2013/PA.Pt. ${ }^{27}$ & 23 Years 1 Months & 12 Years 9 Months \\
\hline$(14)$ & Number 56/Pdt.P/2013/PA.Btg. ${ }^{28}$ & 21 Years 9 Months & 15 Years 1 Months \\
\hline$(15)$ & Number 125/Pdt.P/2014/PA.Kds. ${ }^{29}$ & 21 Years & 14 Years 4 Months \\
\hline$(16)$ & Number 0086/Pdt.P/2015/PA.Bi. ${ }^{30}$ & 23 Years & 14 Years 8 Months \\
\hline$(17)$ & Number 0051/Pdt.P/2014/PA.Bbs ${ }^{31}$ & 19 Years 8 Months & 14 Years 10 Months \\
\hline$(18)$ & Number 0171//Pdt.P/2014/PA.Clp. ${ }^{32}$ & 17 Years 4 Months & 14 Years 4 Months \\
\hline$(19)$ & Number 13/Pdt.P/2013/PA Dmk. ${ }^{33}$ & 18 Years 5 Months & 13 Years 9 Months \\
\hline$(20)$ & Number 116/Pdt.P/2013/PA.Kra. ${ }^{34}$ & 28 Years & 14 Years 3 Months \\
\hline$(21)$ & Number 213/Pdt.P/2015/PA.Kbm. ${ }^{35}$ & 16 Years & 14 Years 5 Months \\
\hline
\end{tabular}

\footnotetext{
${ }^{24}$ The reason presented in the trial was that the child of the Petitioner I had established a love relationship with the child of the applicant II that was so close that it was difficult to separate, and the woman was already 2 months pregnant. The age of the prospective bride is 13 years 11 months, while the age of the potential husband is 21 years 7 months. Farmer's job. Earnings of Rp 2,500,000 every month.

${ }^{25}$ The relationship between the two prospective brides is difficult to separate, besides that the prospective bridegroom has stayed 3 times, if it is not immediately married, it will be feared if they do things that are forbidden by religion.

${ }^{26}$ The relationship between the two brides is very close, so that if they are not married, soon they will do things that are forbidden by religion.

${ }^{27}$ A copy of the Decision, in this case, states that the job of her future husband as a farmer who earns Rp 50.000 every day.

${ }^{28}$ It is very close and inseparable which affects the pregnancy of a prospective bride, an 8-month-old fetus.

${ }^{29}$ The prospective bride has been pregnant for 2 months.

${ }^{30}$ The reason for submitting the marriage dispensation is that if it is not immediately married, acts will be prohibited by Shari'at. The bride and groom were familiar with it for 1 year. Prospective husbands work as builders with an income of IDR 3.000.000 and prospective wives work as food stall servants with an income of IDR 400.000 .

31 The reason for submitting the request, was because the marriage was urgent to be implemented immediately because his daughter had been pregnant for two months due to a husband and wife relationship with the prospective bridegroom. The applicant does not want to endure a moral burden/prolonged disgrace if not immediately married.

32 The marriage must be carried out immediately because the prospective wife has been pregnant for 1 month due to the relationship between the husband and wife with the prospective bridegroom, if it is not immediately married, then it will be feared that they continue to commit acts that violate the Shari'ah law. Potential husbands earn Rp 50.000 every day, but in the copy of the verdict, there is no mention of the prospective husband's work.

${ }^{33}$ Pregnancy is the reason stated in the trial. Prospective wife has been pregnant for 1 month due to intercourse with a potential husband, which starts from dating that has lasted for 1 year. The applicant is very worried that if he is not immediately married, he will violate the law of religion and the state, while the applicant is no longer able to prevent it. Prospective husbands work as builders and earn Rp. 1.000.000 every month.

${ }^{34}$ The reason for applying was because the bride and groom had been engaged for 5 months and the relationship between them was very close, so that if they were not married, immediately they were worried that they would do things that were prohibited according to Shari'a. The prospective husband is a trader, with an average monthly income of Rp. 1.500.000.

${ }^{35}$ Candidates for wives are 7 months pregnant as a result of committing acts like husband and wife 8 times in their parents' homes, which makes parents want to get their children married as soon as possible In the copy of the verdict there is no mention of the execution of the two brides.
} 


\begin{tabular}{|c|c|c|c|}
\hline$(22)$ & Number 0029/Pdt.P/2013/PA.Tg. ${ }^{36}$ & 19 Years 3 Months & 13 Years 6 Months \\
\hline (23) & Number 0029/Pdt.P/2013/PA.Pwt. ${ }^{37}$ & 15 Years 10 Months & 15 Years 6 Months \\
\hline$(24)$ & Number 0084/Pdt.P/2014/PA.SAL. ${ }^{38}$ & 20 Years 10 Months & 14 Years \\
\hline$(25)$ & Number 0166/Pdt.P/2016/PA.Pml. ${ }^{39}$ & 17 Years 7 Months & 14 Years \\
\hline (26) & Number $0007 /$ Pdt.P/2014/PA.Pbg ${ }^{40}$ & 16 Years 7 Months & 14 Years \\
\hline$(27)$ & Number 0068/Pdt.P/2015/PA.Pwr. ${ }^{41}$ & 24 Years & 13 Years 9 Months \\
\hline$(28)$ & Number 146/Pdt.P/2017/PA.Rbg. ${ }^{42}$ & 24 Years & 14 Years 1 Months \\
\hline$(29)$ & Number 0021/Pdt.P/2014/PA.Amb. ${ }^{43}$ & 19 Years 4 Months & 13 Years 8 Months \\
\hline$(30)$ & Number 0009/Pdt.P/2014/PA.Sr. ${ }^{44}$ & 30 Years & 13 Years 8 Months \\
\hline$(31)$ & Number 23/Pdt.P/2015/PA.Ska. ${ }^{45}$ & 18 Years 9 Months & 13 Years 5 Months \\
\hline$(32)$ & Number 0180/Pdt.P/2015/PA.Wsb. ${ }^{46}$ & 18 Years 3 Months & 14 Years 9 Months \\
\hline$(33)$ & Number 034/Pdt.P/2014/PA.Wng. ${ }^{47}$ & 19 Years 8 Months & 14 Years 4 Months \\
\hline$(34)$ & Number 0037/Pdt.P/2015/PA.Tmg. ${ }^{48}$ & 23 Years 4 Months & 13 Years 8 Months \\
\hline$(35)$ & Number 0039/Pdt.P/2016/PA.Kjn. ${ }^{49}$ & 20 Years & 14 Years 6 Months \\
\hline
\end{tabular}

Based on the data above, the average minimum age for filing a marriage dispensation in the Central Java Religious Courts for the female is 13 years, while the

\footnotetext{
${ }^{36}$ That the marriage was very urgent to be carried out, because the relationship between the two brides was very close, if it was not immediately married, it was feared that they would do things that were forbidden by religion. The prospective bridegroom earns Rp. 4.000.000.

${ }^{37}$ The bride and groom have been in love and love for 2 years, so the prospective bride has been pregnant for 5 months in the copy of the decision camouflaged the income of the potential husband.

${ }^{38}$ That the marriage was urgent to be carried out immediately. The bride and groom have known each other for 2 years and have applied. The husband's income is Rp. 1,000,000 every month.

${ }^{39}$ Between two very intimate brides, dating for 1 year 3 months later the bride is known to have been pregnant for 2 months. Prospective husbands earn an average of Rp 50.000 every day.

${ }^{40}$ That the applicant's child was in contact with a prospective daughter-in-law and the pregnancy was known to have been 3 months. In the copy of the decision, no income and employment can be found from the potential husband.

${ }^{41}$ That the marriage was urgent to be implemented immediately because the application had been performed 1 month ago and the prospective husband repeatedly stayed at the house of the prospective bride, if not immediately married was feared to do things that were prohibited.

${ }^{42}$ The reason stated is that the bride and groom had a husband and wife relationship, even though they were not yet pregnant. Prospective husband works as a driver, earning Rp. 3.500.000.

${ }^{43}$ That the marriage was very urgent to continue because the relationship between the two was very close until the applicant's child was 3 months pregnant. Prospective husbands work as breeders and earn Rp. 800,000 every month.

${ }^{44} 6$ months ago the prospective husband's family had applied for the applicant's daughter, besides that the bride and groom were very close and close. If it is not immediately married, what is feared by the two children of the applicant will do the things that are violated by religion.

${ }^{45}$ The reason put forward in the case of dispensation is that the child of the applicant has been pregnant for approximately 2 months due to contact with the prospective bridegroom. Prospective husband works as a welding employee, earning Rp 250.000 every week.

${ }^{46}$ The marriage of the two brides is very urgent because the prospective bride is pregnant according to the Health Check Introduction. Potential husbands work as farm laborers, earning Rp 50,000 every day.

${ }^{47}$ That the marriage was urgent to take place because both of them were engaged 1 year 6 months and the applicant's child was 2 months pregnant. The prospective husband works as a driver but is not known as the owner.

${ }^{48}$ The bride and groom had loved each other since 19 months ago, and the bridegroom's family came to apply so that if they were not married things soon would not be desired. The work and income obtained by the husband are not presented in the copy of the Decision.

${ }^{49}$ The male family has applied, and the two partners are so close that they are trying to separate, their closeness is 6 months. The Decision copy does not explain the job and income of the prospective husband.
} 
submission from the male varies widely. The youngest age is 12 years 9 months (female) and 15 years 10 months (male). Thus, it can also be understood that the judges do not have a standard of age limitation in deciding marital dispensation. Most of the submissions of the dispensations are from females, although there are also 10 submissions filed by males. Another 10 examples are cases submitted by both parties who are both still below the minimum age specified in the marriage law. Then the author compiles the reasons for introducing marriage dispensation into; First, it is caused by a pregnancy out of wedlock in 18 cases out of 35 cases. Second; there are two cases that prospective grooms have often stayed at the house of the prospective brides. Third, there are 15 cases where parents worried about the couple for doing prohibited things by the religion supported by excessive closeness, which is difficult to separate the couple. Besides, the public saw disgrace when a man gets too close to a woman. This condition makes parents want to marry off their children quickly even though they are still underage. ${ }^{50}$

\section{Response and Consideration of Judges in Marriage Dispensation Decisions}

Does the judge have a minimum age limit in establishing cases of marriage dispensation? The question was responded to by six judges at the Bantul and Gunung Kidul Religious Courts. The majority judge gave a statement that the judge did not have a minimum age limit standard in establishing cases of marriage dispensation. the judges only receive passively cases submitted by the parties per their duties and authority in the religious court. whereas, no provisions are regulating the age limit submission of marriage dispensation cases that they decide them according to reasons and facts. ${ }^{51}$ There are two reasons for filing marriage dispensation in the cases above, namely; being pregnant out of wedlock and worrying about doing things that are prohibited by religion. The latter is caused by the couple who have been dating for a long time, or the prospective bridegroom has stayed overnight at the house of the prospective bride. This condition makes parents anxious about the actions of their children so that parents marry their children as soon as possible even though they are underage. The judges certainly have full power to grant or reject the case of the marriage dispensation imposed on him. The judges allow all submissions of marriage dispensation based on benefit. They view a rejected submission will lead to more significant harm. Judges' legal considerations in decisions over the majority are based on Qawaid Fiqhiyyah. One of the legal bases often used by judges in granting requests for marriage dispensation is " "The basis for consideration of judges is all based on benefit.

There are 9 cases out of the 35 cases mentioned above submitted by applicants whose two children are still below the minimum age of marriage. It makes the writer interested in researching more about legal considerations used by the judges so that they grant the case of marriage dispensation. If seen from the reasons of submission in the 9 cases above, it can be classified into two (2) categories; first, 8 cases with a background of pregnancy and 1 example because of dating for one (1) year and three (3) months. The explanation about the consideration of more in-depth judges the author presents in the form of tables, as follows:

\footnotetext{
${ }^{50}$ The phrase from Ms. J while talking with the author on December 8, 2018, in Solo, Central Java.

${ }^{51}$ Interview with Ms. Dra. Endang Sri Hartatik, Drs. Muh Yasin, S.H and Mrs. Dra Hj. Nurhudayah, S.H., M.H in the Wonosari Religious Court and Mr. Drs Rizal Pasi, M.H, Ms. Latifah Setyawati, S.H., M.Hum. Also, Ms. Masmuntiara, S.H., M.H.I at the Bantul Religious Court.
} 
Table 2

\begin{tabular}{ll}
\hline \multicolumn{1}{c}{ Case Number } & \multicolumn{1}{c}{ Legal Judge Considerations } \\
\hline 0007/Pdt.P/2014/PA.Pbg & $\begin{array}{l}\text { Between men and women already have jobs and } \\
\text { their parents are unable to advise both parties. }\end{array}$ \\
\hline 0166/Pdt.P/2016/PA.Pml & $\begin{array}{l}\text { Although the age of men is still underage, } \\
\text { psychologically and psychologically it turns out } \\
\text { they are adults. }\end{array}$ \\
\hline 23/Pdt.P/2015/PA.Ska & $\begin{array}{l}\text { Even though the prospective wife is not yet 16 } \\
\text { years old, but she is fit to carry out the marriage, if } \\
\text { waiting for 16 years it will cause higher mortality. }\end{array}$ \\
\hline 0180/Pdt.P/2015/PA.Wsb & $\begin{array}{l}\text { Prospective wives are already pregnant, and } \\
\text { parents are worried that if their children are not } \\
\text { married, immediately they continue to commit acts } \\
\text { that are prohibited by religion, of course, that is } \\
\text { quite reasonable because they have loved each } \\
\text { other and are trying to separate. }\end{array}$ \\
\hline 0029/Pdt.P/2013/PA.Pwt & $\begin{array}{l}\text { Although the prospective husband is not yet 19 } \\
\text { years old, he already has income and is mature } \\
\text { enough to be a husband, while the future wife is } \\
\text { pregnant. Both are considered capable of carrying } \\
\text { out the rights and obligations of a husband or wife. }\end{array}$ \\
\hline The applicant was unanimously determined to \\
immediately marry the two because they had a \\
strong desire to get married, even the applicant's \\
child uploaded he often did Jima 'until the \\
prospective wife was 7 months pregnant. The \\
panel of judges argued that delaying his marriage \\
would result in greater harm in the form of \\
continuous adultery.
\end{tabular}


Based on the 9 cases above, only 1 case that was filed because it had been dating for 1 year and 3 months. ${ }^{52}$ The age of the prospective bride is 17 years 1 month, and the prospective bride is 13 years 3 months. If examined further from the judges' consideration for granting the request of the applicant, though the girl is 13 years 3 months old, a question arises on whether or not she has matured physically and spiritually. The judges granted the marriage dispensation not focusing on the age of the person who submitted it, but rather on the reasons and considerations of the parties. However, sometimes the judges do not consider the extended benefit in the future, but more on the interest of the moment.

Another supporting factor of the underage marriage is that often people have an opinion about the importance of education for women. Besides, the community measured maturity when a person can make money or work regardless of his age. ${ }^{53}$ The underage marriage is also taken as a solution to cover up the family's shame due to pregnancy out of wedlock. It is supported by the absence of criminal sanctions to the parents who force their children to marry at young ages. ${ }^{54}$ The ease of accessing the internet also makes minors access pornographic contents widely, resulting in pregnancy outside of wedlock. ${ }^{55}$ Marriage carried out by both partners or one of the parties who are still underage causes a lot of negative impacts, one of which is the economic impact or poverty. The underage marriage will increase the birth rate more than the death rate, and as explained by Gavin Jones, the increase in poverty levels can be driven because the birth rate is higher than the mortality rate in an area. ${ }^{56}$

\section{The Dilemma Between Two Interests or Benefit}

The considerations described by the judge in the decision on marriage dispensation reveal that the judge tends to be permissive ${ }^{57}$. The judges' legal considerations in 9 cases of marriage dispensation, in which both parties are still below the minimum age of marriage, focused on benefit and avoiding the greater harm. The benefit is seen from several aspects such as: first, the physical and psychological aspects. In this case, the perpetrator should be seen if he/she is mature enough to carry out marriage. Second, the pregnancy which is caused by sexual intercourse out of wedlock. Third, the income earned by potential husbands or both parties. The consideration due to pregnancy is often used as a great consideration to grant a marriage dispensation request as is reinforced by the statement of two judges in Bantul and Wonosari Religious Court.

Ms. Endang Sri Hartatik explained about the benefits given to applicants who were already pregnant with several considerations as follows:

"The advantages considered to be accepted to request marital dispensation due to pregnancy are: first, if the applicant's child gets married, the child and also the applicant will have a clear status regarding his/her parent for the child and whose husband/wife the applicant is. Second, prospective husbands and wives have responsibility to their children as a result of their relationship. Third, the long-term

52 - the case of marriage dispensation No 066/Pdt.P/2015/PA.Ba.

${ }^{53}$ Dewi Ariani, "Analisa Terhadap Batasan Minimal Usia Pernikahan Dalam UU No 1 Tahun 1974," Artikel Jurusan Syari'ah dan Ekonomi Islam, STAIN Ponorogo 2015, 7-8.

${ }^{54}$ Hardani, "Analisis Tentang, 133.

${ }^{55}$ Mawardi, "Problematika Perkawinan di Bawah Umur," Jurnal Analisa Vol 19 Nomor 02 Juli-Desember 2012, 211.

${ }^{56}$ Dorodjatun Kuntjoro-Jakti, Kemiskinan di Indonesia (Jakarta: Yayasan Obor Indonesia, 1986), 34.

${ }^{57}$ All-around Allow or allow parents who marry their children under the minimum age of marriage. 
consideration emphasized more on the child in the womb as the child must have a clear status of his. Fourth, in order that the impregnating man is responsible for his conduct. ${ }^{58}$

Another consideration was elaborated by Ms. Latifah Setyawati as follows:

"The refusal of marital dispensation submissions due to pregnancy will affect to: First, the female applicant (prospective wife) bears the shame of being pregnant without a husband. Secondly, the conceived child will only have relation to the mother. Besides, the child could not get the birth certificate because the mother does not have a marriage certificate. Third, the refusal also results in the lack of responsibility of the prospective husbands to the prospective wives and children who are still in the womb which may lead to the same acts. The judge was very concerned when he saw by himself underage parties who were pregnant out of wedlock that must be married off anyhow even though in the coming months they came back to ask for a divorce. However, at least the judge had tried to protect the child who was still in the womb."

To decrease the level of underage marriage, it's needed cooperation among various parties. Regional Government of Gunung Kidul, for instance, gives awards to villages that are proven not to have underage marriages. The community also works together by organizing positive activities for children and adolescents. Banaran Village also organized art events, and teaching and learning for teenagers and children in which the funds were obtained through volunteering from villagers. ${ }^{60}$ In addition to the efforts of the community, the family has an essential role in suppressing the level of underage marriage, because the family is the first foundation of education in the family. The parents should have the responsibility to give attention, direction, and good examples so that the child does not easily fall into negative things. ${ }^{61}$

Some studies concerning underage marriage had been done by researchers. Agus Mulyono, for instance, revealed that marriages under 16 years for women and 19 years for men that occurred in Brebes Regency had various impacts such as miscarriages, ${ }^{62}$ inability to solve household problems ${ }^{63}$ due to immaturity ${ }^{64}$, and dependency on parents

\footnotetext{
${ }^{58}$ Interview with Mrs. Dra Endang Sri Hartatik M.SI, which was held on May 16, 2018. She was one of the judges of the Religious Court in Honorary.

${ }^{59}$ Interview with Ms. Latifah Setyawati S.H, M. Hum on April 4, 2018, at the Bantul Religious Court office.

${ }^{60}$ Interview with Mrs. Dra Endang Sri Hartatik M.SI, on March 29, 2018.

${ }^{61}$ Interview with Ms. Dra Hj Masmuntiara, S.H, M.H.I as a judge at the Bantul Religious Court, conducted on April 4, 2018, at the Bantul Religious Court office.

${ }^{62}$ DI informants (guise) in his 14-year-old study, he told me that he had miscarried when he was pregnant with his first child. Besides, he sometimes gets harsh treatment by her husband. This was triggered because the husband did not have money for daily expenses. Sus (surname) also experienced things during her first pregnancy. According to the doctor, the contents of his waist were still too narrow, besides Sus also experienced domestic violence until he passed out for 2 hours. The reason is that the husband does not have money.

${ }^{63}$ Some informants can conclude that when there are problems that affect the economy or other issues that arise, they tend to be unwise in completing them, and sometimes the wife becomes the target of violence committed by the husband.

${ }^{64}$ Agus Mulyono, "Melelisik Perkawinan di Bawah Umur di Kecamatan Larangan, Kabupaten Brebes, Jawa Tengah,” Jurnal Multikultural dan Multireligiun Vol.12 2013.
} 
to supply household needs over the next few years which leads to domestic violence. ${ }^{65}$ Other studies have revealed that the reasons for filing a marriage dispensation are because of the concerns from the parents as the applicants that their child will do things against religious teachings. Marriage is seen as the norm and mechanism of theology to control sexual needs although it did not directly reveal that the marriage proposed was intended to control the sexuality of the applicants' children. ${ }^{66}$ In addition, a research conducted in Klaten Central Java by Endah elaborated some bad impacts of underage marriage. A pregnancy that occurs in women under 18 years is more at risk of giving birth to a baby with a lower weight compared to pregnancies over the age of 19 and furthermore that the infant mortality rate born to mothers under the age of 18 reaches $60 \%$. Poor nutrition and psychically immature mothers also influence it. ${ }^{67}$ In 2013 , Rembang was the district ranked with the highest underage marriages in the Central Java region and with the highest infant mortality. ${ }^{68}$

Other research conducted at Brebes revealed that parents often marry off their children who are still in junior high school due to pregnancy out of wedlock. In some cases at the same condition, they marry off their children by manipulating their ages. ${ }^{69}$ Age manipulation was also found when Prof. Euis conducted research related to child marriage. The age manipulation was also found by The Local Civil Registry Office (KUA) when examining the files of the parties who register the wedding. KUA officers were suspicious of the child and asked for a Family Card to the parents and it turned out that the child who had claimed to be at marriageable age was actually underage. ${ }^{70}$

The occurrence of underage marriages is caused by several factors. First, economic factor. The poverty makes parents marry off their young daughters as a way out to relieve the financial burden because as someone's wife, her rights and obligations will move to her husband. Second, the low education awareness. The low awareness of education extends from the community, parents to children. Third, the parents' concerns because their children are dating someone; it is a disgrace if they are not married immediately. Fourth, the ease of accessing internet makes electronic media very hard to control which leads to accessibility racism or pornography contents for minors. Fifth, parents fear that their child will be an unmarried old woman so that if a man proposes the child, the parents will marry her regardless of her age. ${ }^{71}$

The data Shaw that the minimum age for filing a marriage dispensation in a religious court in Central Java, which is 12-14 years old for women. Supported by previous Research conducted by Susi, it is revealed that girls who give birth at the age

\footnotetext{
${ }^{65}$ Economic life is unstable because it is difficult to find work. Some informants had difficulty fulfilling their needs because they did not have special skills because they only graduated from elementary or junior high school, so they worked as farm laborers whose results were uncertain.

${ }^{66}$ Inayah Rohmaniyah, "Konstruksi Seksualitas dan Relasi Kuasa Dalam Praktik Diskursif Pernikahan Dini,” Jurnal Musãwa, Vol. 16, No. 1, Januari 2017, 44.

${ }^{67}$ Susi Dwi Maret Tati dan Sofwan Indarjo, "Partisipasi Pasangan Pernikahan Dini Terhadap Program Keluarga Berencana," Hygeia Journal Of Public HealTahun Research and Development 1 (2) 2017, 66.

${ }^{68}$ Indarjo, Partisipasi Pasangan, 67.

${ }^{69}$ Khaerul Umam Noer dan Iklilah Muzayyanah Dini Fajriyah, Suara dari Ladang Bawang: Kesehatab Perempuan, Musrembangdes dan AKI yang (katanya) menurun. (Pengalaman Brebes). Jakarta: Pusat Kajian Wanita dan Gender Universitas Indonesia 2015, 101.

${ }^{70}$ Presentation of Prof. Euis Nurlaelawati, M.A., Ph.D. during the National Seminar "Usia Perkawinan Pasca Putusan MK No 22 PUU-XV-2017”. Performed at Jambuluwuk Hotel Yogyakarta on February 8, 2019.

${ }^{71}$ Dwi Rifiani, "Pernikahan Dalam Prespektif Hukum Islam," de Jure, Jurnal Syariah dan Hukum, Volume 3 Nomor 2, Desember 2011, 126-127.
} 
of 10-14 years have a risk of dying five times greater than girls who marry at the age of 20-24 years. Besides that, the very young age has an impact on the burden on girls for the responsibilities and essential roles that should be carried out by adults, this affects the psychological and emotional strain that is great for them. ${ }^{72}$ The ideal marriage is done at least 21 years of age (male and female) because in that age range men and women are considered to be physically and psychologically mature enough. ${ }^{73}$ Often common people assume that marriage avoids sinful acts; this is not entirely true because the purpose of marriage is not only to avoid sin but also worth worship and proof of obedience to God. This can be obtained if the bride and groom know very well about the purpose of the marriage to be performed and also build mental, physical and social readiness. ${ }^{74}$ Besides, people who have matured mentally and physically have not entirely been able to solve problems in the family, especially for couples who are underage. ${ }^{75}$

\section{Conclusion}

From the discussion above, several conclusions can be given in this section. First, the Judge does not have a minimum age standard in establishing cases of marriage dispensation where the 12-year-old author's findings are still granted. The lowest age for filing a marriage dispensation in Central Java is 12 years 9 months (female) and 15 years 10 months (male), while the minimum average age for submission is 13 years. Secondly, those who often propose marriage dispensation are women, although men also submit some cases. Third, the judge's consideration that is used for the parties who are still underage is a benefit. The benefits are considered from the aspect of work, psychological, physical maturity. However, the problem found was more on temporary issues and did not have an impact on the long term. Efforts to reduce the level of underage marriage can be made in collaboration with various parties. Parents and families have a starting point to reduce the level of young marriage.

\section{Bibliography}

Ariani, Dewi, "Analisa Terhadap Batasan Minimal Usia Pernikahan dalam UU No 1 Tahun 1974," Artikel Jurusan Syari'ah dan Ekonomi Islam, STAIN Ponorogo 2015.

Hardani, Sofia, "Analisis Tentang Batas Umur untuk Melangsungkan Perkawinan Menurut Perundang-Undangan di Indonesia," An-Nida' : Jurnal Pemikiran Islam, Vol. 40, No 2 Juli- Agustus 2015.

Interview with Ms. Dra. Endang Sri Hartatik, Drs. Muh Yasin, S.H and Mrs. Dra Hj. Nurhudayah, S.H., M.H at the Wonosari Religious Court

Interview with Mr. Drs Rizal Pasi, M.H, Ms. Latifah Setyawati, S.H., M.Hum, and Ms. Masmuntiara, S.H., M.H.I at the Bantul Religious Court.

Kompilasi Hukum Islam

Kustini, Menelusuri Makna di Balik Fenomena Perkawinan di Bawah Umur dan Perkawinan Yang Tidak Dicatatkan (Jakarta: Badan Litbang dan Diklat, Kementrian Agama RI 2013.

\footnotetext{
${ }^{72}$ Subdirektorat Statistik Rumah Tangga, Kemajuan yang Tertunda: Analisis Data Perkawinan Usia Anak Indonesia, (Jakarta: Badan Pusat Statistik 2015), 11-12.

${ }^{73}$ Taufik Mandailing, Good Married Raih Asa Gapai Bahagia, (Yogyakarta: IDEA Press, 2012), 105

${ }^{74}$ Mandailing, Good Married, 106-107.

${ }^{75}$ Ariani, “Analisa Terhadap, 15.
} 
Lufaefi, "Upgrading Hukum Perkawinan Di Indonesia: Upaya Pencegahan Kekerasan Terhadap Kaum Perempuan,” Jurnal Musãwa, Vol. 16, No. 1, Januari 2017.

Mahkamah Konstitursi Republik Indonesia "Usia Minimal 16 Tahun Bagi Perempuan untuk Menikah Tidak Langgar Konstitusi," http://www.mahkamahkonstitusi.go.id/index.php?page=web.Berita\&id=11150\#. Wk4HFDR6O00 accessed on December 20, 2018.

Mandailing, Tuafik, Good Married Raih Asa Gapai Bahagia, Yogyakarta:IDEA Press, 2012.

Mawardi, "Marmiati, Problematika Perkawinan di Bawah Umur," Jurnal Analisa Vol 19 Number 02 Juli-Desember 2012.

Marhumah, Hak-hak dalam Keluarga Yogyakarta: Pusat Studi Wanita UIN Sunan Kalijaga, 2009.

Marmi, Kesehatan Reproduksi. Yogyakarta: Pustaka Pelajar, 2014.

Mulyono, Agus, "Melelisik Perkawinan di Bawah Umur di Kecamatan Larangan, Kabupaten Brebes, Jawa Tengah," Jurnal Multikultural dan Multireligiun Vol.12 2013.

Noer, Khaerul Umam dan Iklilah Muzayyanah Dini Fajriyah, Suara dari Ladang Bawang: Kesehatab Perempuan, Musrembangdes dan AKI yang (katanya) menurun. (Pengalaman Brebes). Jakarta: Pusat Kajian Wanita dan Gender Universitas Indonesia 2015

Purwaningsih, Endah dan Ria Tri Setyaingsih, Hubungan Pola Assuh Orang Tua dengan Kejadian Pernikahan Usia Dini di Desa Jambu Kidul, Ceper, Klaten. Jurnal Ivolusi Kebidanan, Vol. 4, No 7, Januari 2014.

Putusan Mahkamah Konstitusi No 22 / PUU-XV / 2017.

Putusan Mahkamah Konstitusi No 30-74 / PUU-XXI / 2014.

Presentation of Mr. Dr. Wahidudin Adams (he is one of the Constitutional Court Judges who ruled Case No: 22 / PUU-XV / 2017 concerning Marriage Age) at a national seminar with the theme "Usia Perkawinan Pasca Putusan MK No 22 PUU-XV2017". He has performed at Jambuluwuk Hotel Yogyakarta on February 8, 2019.

Presentation of Prof. Euis Nurlaelawati, M.A., Ph.D. during the National Seminar "Usia Perkawinan Pasca Putusan MK No 22 PUU-XV-2017'. Performed at Jambuluwuk Hotel Yogyakarta on February 8, 2019.

Rifiani, Dwi, "Pernikahan dalam Prespektif Hukum Islam," de Jure, Jurnal Syariah dan Hukum, Volume 3 Number 2, Desember 2011.

Rohmaniyah, Inayah, "Konstruksi Seksualitas dan Relasi Kuasa dalam Praktik Diskursif Pernikahan Dini," Jurnal Musãwa, Vol. 16, No. 1, Januari 2017.

Subdirektorat Statistik Rumah Tangga, Kemajuan yang Tertunda: Analisis Data Perkawinan Usia Anak Indonesia, Jakarta: Badan Pusat Statistik 2015.

Tati, Susi Dwi Maret dan Sofwan Indarjo, "Partisipasi Pasangan Pernikahan Dini Terhadap Program Keluarga Berencana," Higeia Journal Of Public HealTahun Research and Development 1 (2) 2017.

Undang-Undang Perkawinan No 1 tahun 1974 Tentang Perkawinan. 